\title{
Peach palm flour (Bactris gasipae KUNTH): potential application in the food industry
}

\author{
Márlia Barbosa PIRES ${ }^{1}$, Edna Regina AMANTE², Alessandra Santos LOPES ${ }^{1}$, \\ Antonio Manoel da Cruz RODRIGUES ${ }^{1}$, Luiza Helena Meller da SILVA ${ }^{1 \star}$
}

\begin{abstract}
Peach palm flours prepared from the landraces microcarpa (MIF), mesocarpa (MEF), and macrocarpa (MAF) were assessed for their functional and morphological characteristics. The flours had moisture contents in accordance with the current legislation, considerable lipid $(\geq 3.95 \%)$ and carbohydrate $(\geq 66.68 \%)$ contents, and potential as an energy source $(\geq 300 \mathrm{kcal} / 100 \mathrm{~g})$. MEF and MAF can be considered rich in dietary fibers since their fiber contents were above $6 \mathrm{~g} / 100 \mathrm{~g}$, which contributes to the nutritional enrichment of products prepared with those flours. The assessment of the technological properties, WAC $(\geq 255 \%)$ and OAC ( $\geq 65 \%)$ showed the peach palm flours can be used as raw material in different products such as breads, cakes, meat products, and breaded foods, thus adding energy, nutritional, and economic value. It is worth pointing out that peach palm is gluten free, hence it is an option for the development of new products targeted at consumers with celiac disease.
\end{abstract}

Keywords: flour; technological properties; peach palm; Bactris gasipae KUNTH.

Practical Application: use in the formulation of different gluten-free products.

\section{Introduction}

The broad biodiversity of the Brazilian Amazon comprehends about 220 species of edible fruits, which represents around $4 \%$ of the diversity of fruits native to Brazil (Neves et al., 2012). Valuing the typical fruits of the Amazon region and learning new information on those food sources drives the sustainable development of regional raw materials (Hiane et al., 2003) both in the Brazilian Amazon and in neighbor countries featuring this biome.

Among Amazonian cultures, peach palm three (Bactris gasipaes Kunth) stands out with the production of peach palm fruit and heart of palm. The fruit is edible with pleasant flavor and has high nutritional and energy values while carrying lipids, proteins, carotenoids (pro-vitamin A), vitamins B and C, selenium, and iron (Santos et al., 2008). Peach palm fruit varieties are differentiated according to the fruits' skin color, lipid content, and presence or absence of seeds. However, peach palm trees can be classified into microcarpa, mesocarpa, and macrocarpa landraces based on pulp thickness (Yuyama, 2011). The different compositions of those fruits enable the obtention of different food products such as peach palm oil and flour.

Peach palm flour is obtained from the pulp of the fruit (Ferreira \& Pena, 2003). This flour is rich in starch and can be used to prepare lighter products such as cakes, biscuits, and pasta. This is a way of diversifying the demand for peach palm and enables its year-round consumption since it is a seasonal fruit. Given it is gluten free (Clement \& Urpí, 2005), the flour can be used to prepare products for population groups with restricted diets, such as persons with celiac disease.
The use of peach palm flour as an ingredient for the formulation of different products requires studies on its technological properties such as fat absorption capacity, desirable to improve palatability; emulsifying capacity so it can replace ingredients in emulsion systems; and water absorption capacity, a relevant property for application in meat products, breads, and cakes (Porte et al., 2011).

Recommending peach palm flours produced from fruits of different landraces requires preliminary studies on their nutritional, morphological, and technological characteristics. Aiming to value the typical fruits of the Amazon region so as to meet the current market demand for innovative and healthful products, the present study assessed the physicochemical and morphological characteristics and the technological properties of peach palm flours produced from the microcarpa, mesocarpa, and macrocarpa landraces. That allows alternatives to be proposed for the industrial application of those flours in the development of several gluten-free products.

\section{Material and methods}

\subsection{Raw material}

The peach palm fruits were purchased in street markets in the city of Belém, PA, ( $\left.01^{\circ} 27^{\prime} 21^{\prime \prime} \mathrm{S}, 48^{\circ} 30^{\prime} 16^{\prime \prime} \mathrm{W}\right)$, in the North region of Brazil, in $5 \mathrm{~kg}$ batches collected between March and June, which corresponds to the harvest period of the fruits and to the replicates needed for the experimental design. The fruits were then transported to the laboratories of UFPA's

${ }^{1}$ Laboratorio de Medidas Fisicas - LAMEFI, Programa de pós graduação em Ciência e Tecnologia de Alimentos - PPGCTA, Universidade Federal do Pará- UFPA, Belém, PA, Brasil

${ }^{2}$ Centro de Ciências Agrarias - CCA, Universidade Federal de Santa Catarina, Campus Itacorubi, Florianópolis, SC, Brasil

*Corresponding author: lhmeller@ufpa.br 
Graduate Program in Food Science and Technology (PPGCTA) and classified regarding the landraces based on their physical characteristics according to Yuyama (2011).

\subsection{Flour preparation}

After the physical characterization, the fruits were separated into batches according to their landrace, hygienized with a $100 \mathrm{ppm}$ sodium hypochlorite solution, peeled, and cut into four parts with seed separation. The fruits were dried in a fixed-bed dryer with forced air circulation at $55^{\circ} \mathrm{C}$ for $42 \mathrm{~h}$. After drying, the samples were ground in a hammer mill, vacuum packaged in polyethylene bags, and stored at room temperature until the moment of analysis. The peach palm flour batches were coded as MIF (microcarpa peach palm flour), MEF (mesocarpa peach palm flour), and MAF (macrocarpa peach palm flour).

\subsection{Physicochemical characterization of the peach palm fruits and flours}

The analyses of moisture, lipids, ashes, proteins, fibers, water activity $\left(\mathrm{a}_{\mathrm{w}}\right), \mathrm{pH}$, and acidity of the fruits and flours were performed according to the Association Of Official Analytical Chemists (2002). The caloric value was calculated based on the percentage composition using Atwater coefficients (Watt \& Merrill, 1963). Color was analyzed by a Minolta CR400 colorimeter using the CIE system to assess the chromaticity coordinates $\mathrm{L}^{\star}$ for luminosity, $\mathrm{a}^{*}$ for red color intensity, and $\mathrm{b}^{*}$ for yellow color intensity.

\subsection{Morphological characterization}

The samples were metallized with platinum for scanning electron microscopy (SEM) evaluation using a ZEISS LEO-1430 electron microscope. The analysis conditions for the secondary electron imaging were working distance of $15 \mathrm{~mm}$ and constant acceleration voltage.

\subsection{Paste properties}

The viscoamylographic behavior of the peach palm flours was measured in an RVA 4500 Rapid Visco Analyser (RVA - PERTEN, Australia) using samples with known moisture contents. $3.5 \mathrm{~g}$ of peach palm flour were weighed, whose operational parameters were initial temperature of $50{ }^{\circ} \mathrm{C}$ under stirring at $960 \mathrm{rpm}$ for $10 \mathrm{~s}$ for sample homogenization followed by stirring at $160 \mathrm{rpm}$ at $50{ }^{\circ} \mathrm{C}$, heating at $95{ }^{\circ} \mathrm{C}$, and cooling at $50{ }^{\circ} \mathrm{C}$ according to AACC methodology no. 76-21 (AACC, 2000).

\subsection{Technological properties}

The technological properties assessed for the peach palm flours were oil absorption capacity (OAC) determined according to Linet et al. (1974); water absorption capacity (WAC) calculated according to Sosulski (1962); and emulsifying activity and stability (EA and EE) determined according to the method by Dench et al. (1981).

\subsection{Infrared absorption spectroscopy analyses}

The flour samples were analyzed in a MICROLAB FTIR 630 infrared absorption spectrophotometer using the software Agilent MicroLab in absorbance mode using eight scans and $16 \mathrm{~cm}^{-1}$ resolution (Smith, 1979).

\subsection{Statistical analysis}

All analyses were carried out in triplicate and the data were expressed as arithmetic means and standard deviation (SD). The data underwent analysis of variance (ANOVA) and Tukey's test at $5 \%$ significance level.

\section{Results and discussions}

\subsection{Physicochemical characterization of the peach palm fruits and flours}

The fruits' landrace classification was performed through biometry. The mean values found for the different peach palm landraces were: microcarpa - length $(\mathrm{cm}) 3.24 \pm 0.20$, diameter (cm) $2.13 \pm 0.15$, and weight $(\mathrm{g}) 8.24 \pm 1.34$; mesocarpa length $(\mathrm{cm}) 4.40 \pm 0.22$, diameter $(\mathrm{cm}) 3.61 \pm 0.17$, and weight (g) $35.37 \pm 4.43$; and macrocarpa - length $(\mathrm{cm}) 5.80 \pm 0.33$, diameter $(\mathrm{cm}) 4.47 \pm 0.20$, and weight $(\mathrm{g}) 70.67 \pm 1.93$. Landrace classification was based on information reported by Yuyama (2011), i.e., microcarpa (fruit $<20 \mathrm{~g}$ ), mesocarpa (fruit 21-70 g), and macrocarpa (fruit $>70 \mathrm{~g}$ ). The physical variations can be justified by several factors such as genetics, number of fruits per plant, and competition among developing organs (Sena et al., 2009). After landrace classification, the fruits were characterized regarding their centesimal composition (Table 1).

It can be seen that the fruits of different landraces have high nutritional value and significant differences among their compositions. Macrocarpa fruits had the lowest moisture values $\left(47.98 \pm 0.14 \mathrm{~g} .100 \mathrm{~g}^{-1}\right)$, which contributes to those fruits being little consumed as they are considered dry (Yuyama, 2011).

Microcarpa fruits had the highest lipid contents $\left(6.88 \pm 0.03 \mathrm{~g} .100 \mathrm{~g}^{-1}\right)$, which, according to Porte et al. (2011), is

Table 1. Centesimal composition of peach palm (Bactris gasipaes Kunth) fruits of different landraces.

\begin{tabular}{|c|c|c|c|}
\hline$\frac{\text { COMPONENTS }}{\left(\mathrm{g} .100 \mathrm{~g}^{-1}\right)}$ & MIP & MEP & MAP \\
\hline Moisture & $62.43 \pm 0.12^{\mathrm{b}}$ & $63.96 \pm 0.50^{\mathrm{a}}$ & $47.98 \pm 0.14^{c}$ \\
\hline Lipids & $6.88 \pm 0.03^{\mathrm{a}}$ & $2.62 \pm 0.08^{c}$ & $4.42 \pm 0.07^{\mathrm{b}}$ \\
\hline Ashes & $2.74 \pm 0.06^{\mathrm{a}}$ & $2.22 \pm 0.07^{b}$ & $0.80 \pm 0.00^{c}$ \\
\hline Proteins & $3.90 \pm 0.01^{\mathrm{a}}$ & $2.00 \pm 0.07^{c}$ & $2.64 \pm 0.04^{b}$ \\
\hline Carbohydrates & $24.05 \pm 0.04^{c}$ & $29.20 \pm 0.54^{\mathrm{b}}$ & $44.16 \pm 0.09^{\mathrm{a}}$ \\
\hline$a_{w}$ & $0.98 \pm 0.00^{\mathrm{a}}$ & $0.99 \pm 0.00^{\mathrm{a}}$ & $0.99 \pm 0.00^{\mathrm{a}}$ \\
\hline $\mathrm{pH}$ & $6.09 \pm 0.19^{\mathrm{b}}$ & $6.30 \pm 0.04^{\mathrm{a}}$ & $6.16 \pm 0.04^{b}$ \\
\hline $\begin{array}{l}\text { Titratable acidity } \\
\left(\mathrm{mL} .100 \mathrm{~g}^{-1}\right)\end{array}$ & $2.36 \pm 0.15^{\mathrm{a}}$ & $2.14 \pm 0.06^{\mathrm{a}}$ & $1.21 \pm 0.96^{\mathrm{b}}$ \\
\hline $\begin{array}{l}\text { Caloric value } \\
\left(\text { kcal. } 100 \mathrm{~g}^{-1}\right)\end{array}$ & $173.76 \pm 0.5^{\mathrm{b}}$ & $148.40 \pm 1.8^{c}$ & $227.01 \pm 0.35^{\mathrm{a}}$ \\
\hline
\end{tabular}

Components in wet basis; mean values of three replicates with their standard deviations; different letters among the columns indicate difference at $95 \%$ significance. MIP - microcarpa peach palm; MEP - mesocarpa peach palm; MAP - macrocarpa peach palm. 
desirable to improve the palatability of foods, thus justifying the preference of Amazonian consumers for this landrace.

According to Ferreira \& Pena (2003), starch-rich peach palm fruits can be used to produce flours, which is the case of macrocarpa with its high carbohydrate content and low moisture compared to the other landraces.

$\mathrm{pH}$ values remained in the neutral range and are close to those of fruits of Amazonian palm trees such as maripa palm $(6.35 \pm 0.2)$, tucuman $(6.12 \pm 0)$, and peach palm $(6.15 \pm 0.3)$ (Santos et al., 2017).

The Brazilian and international food-quality regulatory agencies have set no standards for peach palm flour. Thus, the standards of other flours established by CNNPA Resolution no. 12 of ANVISA (Brasil, 1978), which regulates quality parameters for wheat flour, were used as reference. All flours prepared are in accordance with the requirements of the legislation concerning moisture and $\mathrm{a}_{\mathrm{w}}$ (Table 2). Based on the $\mathrm{a}_{\mathrm{w}}$ values found for the peach palm flours, final moisture below $12 \%$ is recommended to ensure the microbiological stability of these products $($ aw $<0.6)$.

The analyses showed that MIF had significantly higher lipid values $\left(7.40 \pm 0.20 \mathrm{~g} .100 \mathrm{~g}^{-1}\right)$ compared to MEF $\left(4.73 \pm 0.04 \mathrm{~g} .100 \mathrm{~g}^{-1}\right)$ and MAF $\left(3.95 \pm 0.13 \mathrm{~g} .100 \mathrm{~g}^{-1}\right)$. MAF had the highest carbohydrate content $\left(75.02 \pm 0.23 \mathrm{~g} .100 \mathrm{~g}^{-1}\right)$ compared to $\operatorname{MIF}\left(67.32 \pm 0.4 \mathrm{~g} .100 \mathrm{~g}^{-1}\right)$ and $\operatorname{MEF}\left(66.68 \pm 0.92 \mathrm{~g} .100 \mathrm{~g}^{-1}\right)$. According to Santos et al. (2011), the different peach palm landraces have different chemical compositions. On average, microcarpa has higher lipid content, a characteristic that is appreciated by consumers, whereas macrocarpa has higher carbohydrate content, which justifies it being known as a "dry" peach palm (Bolanho et al., 2014).

In Brazil, according to Resolution no. 52 (Brasil, 2012), which regulates complementary nutritional information, a

Table 2. Peach palm (Bactris gasipaes Kunth) flour composition.

\begin{tabular}{lrrr}
\hline \multicolumn{1}{c}{ Components } & \multicolumn{1}{c}{ MIF } & \multicolumn{1}{c}{ MEF } & \multicolumn{1}{c}{ MAF } \\
\hline Moisture $\left(\mathrm{g} .100 \mathrm{~g}^{-1}\right)$ & $12.21 \pm 0.41^{\mathrm{a}}$ & $12.58 \pm 0.51^{\mathrm{a}}$ & $9.60 \pm 0.17^{\mathrm{b}}$ \\
Lipids $\left(\mathrm{g} .100 \mathrm{~g}^{-1}\right)$ & $7.40 \pm 0.20^{\mathrm{a}}$ & $4.73 \pm 0.04^{\mathrm{b}}$ & $3.95 \pm 0.13^{\mathrm{c}}$ \\
Ashes $\left(\mathrm{g} .100 \mathrm{~g}^{-1}\right)$ & $2.61 \pm 0.08^{\mathrm{a}}$ & $1.85 \pm 0.01^{\mathrm{b}}$ & $1.22 \pm 0.03^{\mathrm{c}}$ \\
Proteins $\left(\mathrm{g} .100 \mathrm{~g}^{-1}\right)$ & $4.62 \pm 0.03^{\mathrm{a}}$ & $3.20 \pm 0.02^{\mathrm{b}}$ & $2.46 \pm 0.02^{\mathrm{c}}$ \\
Carbohydrates $\left(\mathrm{g} .100 \mathrm{~g}^{-1}\right)$ & $67.32 \pm 0.4^{\mathrm{b}}$ & $66.68 \pm 0.92^{\mathrm{b}}$ & $75.02 \pm 0.23^{\mathrm{a}}$ \\
Total fibers (g.100 g-1) & $5.47 \pm 0.70^{\mathrm{c}}$ & $10.82 \pm 0.43^{\mathrm{a}}$ & $7.67 \pm 0.18^{\mathrm{b}}$ \\
Insoluble fibers $\left(\mathrm{g} .100 \mathrm{~g}^{-1}\right)$ & $5.03 \pm 0.40^{\mathrm{c}}$ & $10.04 \pm 0.32^{\mathrm{a}}$ & $7.23 \pm 0.41^{\mathrm{b}}$ \\
Soluble fibers $\left(\mathrm{g} .100 \mathrm{~g}^{-1}\right)$ & $0.44 \pm 0.29^{\mathrm{a}}$ & $0.78 \pm 0.72^{\mathrm{a}}$ & $0.04 \pm 0.27^{\mathrm{a}}$ \\
$\mathrm{a}_{\mathrm{w}}$ & $0.62 \pm 0.00^{\mathrm{a}}$ & $0.61 \pm 0.00^{\mathrm{a}}$ & $0.47 \pm 0.03^{\mathrm{b}}$ \\
pH & $5.46 \pm 0.02^{\mathrm{c}}$ & $5.78 \pm 0.00^{\mathrm{b}}$ & $5.92 \pm 0.03^{\mathrm{a}}$ \\
Titratable acidity & $6.30 \pm 0.96^{\mathrm{a}}$ & $6.60 \pm 0.033^{\mathrm{a}}$ & $3.46 \pm 0.10^{\mathrm{b}}$ \\
(mL.100 g $)$ & & & \\
$\mathrm{L}^{*}$ & $72.93 \pm 0.55^{\mathrm{c}}$ & $79.18 \pm 0.37^{\mathrm{b}}$ & $81.61 \pm 0.13^{\mathrm{a}}$ \\
$\mathrm{a}^{*}$ & $13.60 \pm 0.05^{\mathrm{a}}$ & $0.32 \pm 0.17^{\mathrm{b}}$ & $-1.12 \pm 0.10^{\mathrm{c}}$ \\
$\mathrm{b}^{*}$ & $66.74 \pm 0.40^{\mathrm{a}}$ & $42.84 \pm 0.60^{\mathrm{b}}$ & $27.59 \pm 0.40^{\mathrm{c}}$ \\
Caloric value & $300.07 \pm 2.46^{\mathrm{a}}$ & $326.67 \pm 2.01^{\mathrm{a}}$ & $321.28 \pm 1.64^{\mathrm{a}}$ \\
(kcal.100 g $\left.^{-1}\right)$ & & & \\
\hline
\end{tabular}

Mean values of three replicates with their standard deviations. Different letters among the columns represent a difference at $95 \%$ significance. In dry basis. MIF - microcarpa peach palm flour; $\mathrm{MEF}$ - mesocarpa peach palm flour; MAF - macrocarpa peach palm flour solid food can be considered a source of dietary fibers when the finished product contains $3 \mathrm{~g} .100 \mathrm{~g}^{-1}$ fibers and, when a food has a value twice as high, it is considered as having high dietary fiber content. Therefore, MIF can be considered a source of dietary fibers while MEF and MAF can be considered rich in fibers. The peach palm flours had total dietary fiber contents close to that of whole wheat flour $\left(10.7 \mathrm{~g} .100 \mathrm{~g}^{-1}\right)$ (Chaudhary \& Weber, 1990). It is noteworthy that, in the case of peach palm flours, the highest fiber concentration corresponds to the insoluble fraction, which remains intact along the entire human digestive tract. The growing consumer demand for fiber-rich foods has led many manufacturers to incorporate more fibers into their products, thus showing that peach palm flour may be used as a raw material in the development of new products (Buttriss \& Stokes, 2008).

Peach palm flours can be considered excellent sources of calories since their caloric values are close to those of conventional flours such as whole wheat and defatted soybean of 339 and $329 \mathrm{kcal} 100 \mathrm{~g}^{-1}$, respectively (United State Department of Agriculture, 2002).

Statistical differences in color were observed among the peach palm flours produced. MIF had more yellow color (66.74 \pm 0.40$)$ compared to MEF (42.84 \pm 0.60$)$ and MAF $(27.59 \pm 0.40)$. Carotenoid content may justify such colors (Ribeiro \& Seravalli, 2004), which is an important attribute for those flours since, in general, conventional flours do not have carotenoids.

\subsection{Infrared absorption spectroscopy analyses}

The FTIR spectra found for the peach palm flours are similar to those of corn and wheat flours (Cremer \& Kaletunç, 2003). Figure $1(\mathrm{a}-\mathrm{c})$ presents the spectra for peach palm flour samples.

The spectra have a broad peak in the $\mathrm{OH}$ elongation region in the neighborhood of 3,450 $\mathrm{cm}^{-1}$ (point 1 in Figure $1 \mathrm{a}-\mathrm{c}$ ). The high lipid content of the samples (MEF and MIF) results in a more pronounced $\mathrm{CH}$ elongation region, in which the main peak is at 2,900 $\mathrm{cm}^{-1}$ (point 2), which is characteristic of $\mathrm{CH}_{2}$. The MIF and MEF samples are followed by a second, smaller peak and more marked at $2,850 \mathrm{~cm}^{-1}\left(\mathrm{CH}_{2}\right.$, symmetric), point 3 , which is not apparent in the spectrum of MAF due to the lower lipid content in this sample compared to the other flours. The difference in lipid content is evidenced by the elongation of the carbonyl ester band at $1,740 \mathrm{~cm}^{-1}$, appearing at point 4 , found only for the MIF and MEF samples.

The first band that characterizes the proteins is found in spectrum point 5 . This band represents the amide I band $\left(\mathrm{C}=\mathrm{O}\right.$ primary elongation vibration) and peaks at $1,650 \mathrm{~cm}^{-1}$. According to Cooper (1995), it is well established that the $\mathrm{H}-\mathrm{O}-\mathrm{H}$ flexion vibrations of water show strong absorbance close to $1,640 \mathrm{~cm}^{-1}$, around which the amide I band absorbs. In addition, a weak C-O-H deformation of the starch glucose ring contributes at $1,650 \mathrm{~cm}^{-1}$. The amide II band is represented by point 6 largely because of the $\mathrm{NH}$ flexion vibration observed at $1,490 \mathrm{~cm}^{-1}$.

The fingerprint region at $1,300-900 \mathrm{~cm}^{-1}$, close to point 7 , possibly features carbohydrates. All peach palm flours exhibited 

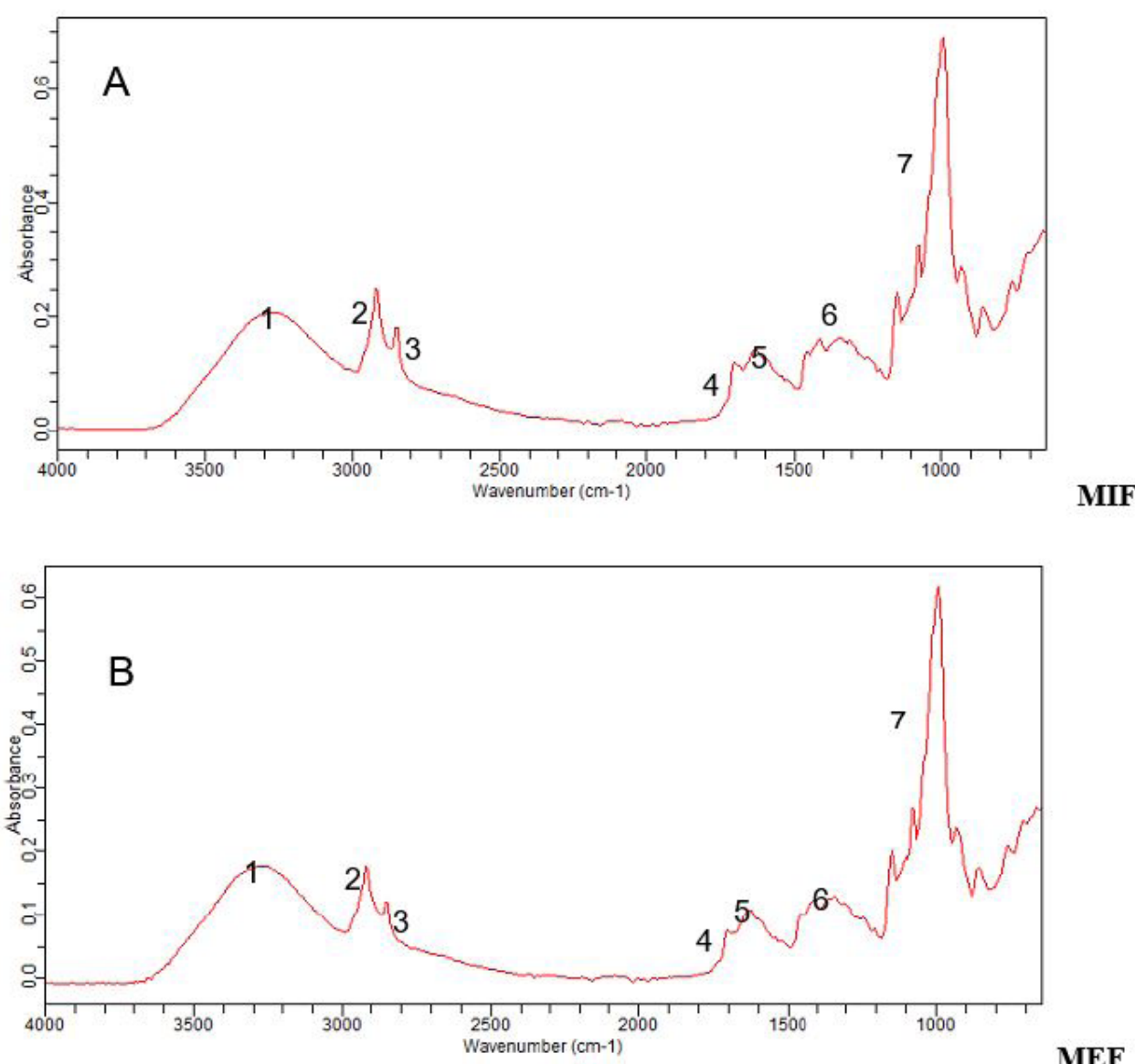

MEF

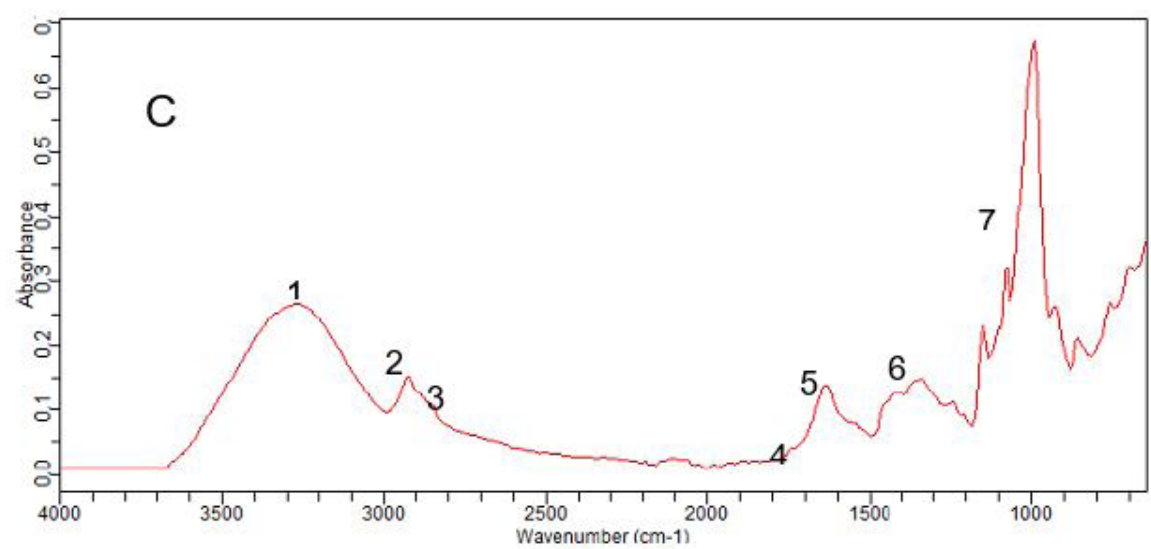

MAF

Figure 1. Absorption spectra in the infrared region of peach palm flours. A = MIF - microcarpa peach palm; $B=M E F-$ mesocarpa peach palm; $\mathrm{C}=\mathrm{MAF}-$ macrocarpa peach palm.

strong characteristic peaks at $1,190,1,100$, and $1,050 \mathrm{~cm}^{-1}$, related to $\mathrm{C}-\mathrm{C}-\mathrm{O}, \mathrm{C}-\mathrm{C}$, and $\mathrm{O}-\mathrm{C}-\mathrm{O}$ deformations, characteristics of starch.

The results found are close to those obtained in the percentage composition analyses using traditional methods. That enables using $\mathrm{x}$-ray analysis to replace conventional analyses to determine composition since a small sample is sufficient for a result of all components in a single assay, with the advantage of a quick, low-cost method compared to traditional ones.

\subsection{Morphological characterization}

The micrographs presented in Figure 2 enable assessing the morphology of peach palm flour particles and show the starch structure (A) with rounded characteristics, slightly flattened in one of its ends, non-homogeneous sizes, and structures similar to dietary fibers (B). The drying temperature employed to obtain the flours $\left(55^{\circ} \mathrm{C}\right)$ did not impact the integrity of starch granules since the gelling temperature of peach palm starch has been identified as being over $85^{\circ} \mathrm{C}$. 

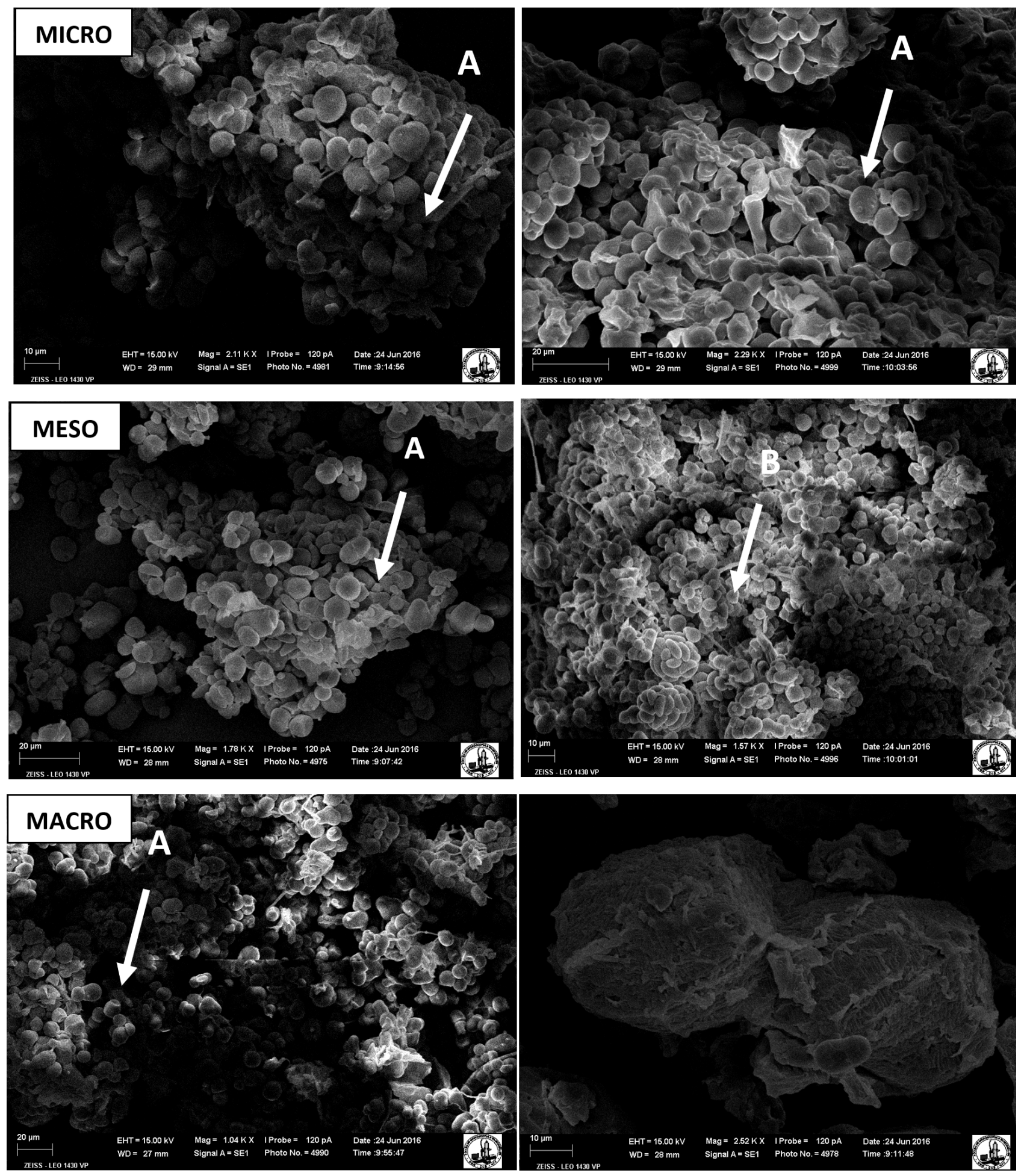

Figure 2. Scanning electron microscopy of the peach palm flours MIF, MEF and MAF. A: starch structure e B: structures similar to dietary fibers.

\subsection{Technological properties of peach palm flour}

Table 3 presents the viscosity profiles of the flours studied. Maximum and minimum viscosity, breakdown, and downgrading are significantly lower in MEF, which can be justified by the high insoluble fibers content in this landrace. According to Sena et al. (2009), insoluble fibers have low water solubility, high water absorption capacity, and high liquid retention, which may have impacted the paste formation of peach palm flour prepared from the mesocarpa landrace.

The initial paste temperatures for the flours studied were $94.70 \pm 0.25$ for MIF, $94.90 \pm 2.00$ for MEF, and $94.92 \pm 0.02$ for MAF. Besides indicating the minimum temperature at which 
Table 3. Paste properties of peach palm flours obtained in a Rapid Visco Analyser (RVA).

\begin{tabular}{|c|c|c|c|c|c|c|}
\hline & $\mathrm{Tp}$ & VM $95^{\circ} \mathrm{C}$ & VF $50^{\circ} \mathrm{C}$ & Breakdown & Downgrading & tp \\
\hline Flours & $\left({ }^{\circ} \mathrm{C}\right)$ & $(\mathrm{cp})$ & $(\mathrm{cp})$ & (cp) & (cp) & $(\min )$ \\
\hline MIF & $94.70 \pm 0.25^{\mathrm{a}}$ & $315.00 \pm 4.00^{\mathrm{b}}$ & $313.5 \pm 5.50^{\mathrm{b}}$ & $37.50 \pm 1.00^{\mathrm{b}}$ & $36.33 \pm 0.50^{b}$ & $12.78 \pm 0.09^{\mathrm{a}}$ \\
\hline MEF & $94.90 \pm 2.00^{\mathrm{a}}$ & $102.96 \pm 2.00^{c}$ & $97.33 \pm 1.50^{c}$ & $26.63 \pm 2.1^{c}$ & $21.00 \pm 1.00^{c}$ & $11.20 \pm 2.00^{\mathrm{a}}$ \\
\hline MAF & $94.92 \pm 0.02^{\mathrm{a}}$ & $454.00 \pm 2.00^{\mathrm{a}}$ & $454.00 \pm 2.00^{\mathrm{a}}$ & $127 \pm 0.00^{\mathrm{a}}$ & $127 \pm 0.00^{\mathrm{a}}$ & $12.93 \pm 0.00^{\mathrm{a}}$ \\
\hline
\end{tabular}

Different letters among the rows represent difference at $95 \%$ significance. Tp: Initial paste temperature; VM: Maximum viscosity; VF: Final viscosity; tp: Peak time. cp: centipoise.

the granules undergo gelling, the paste temperature indicates the temperature at which viscosity increases during the heating period (Singh et al., 2011). It can be said that the flours produce viscous pastes regardless of the variety, which increase their potential industrial application since they all have the same gelling characteristics. Overall, the gelling temperature of the starches present in roots and tubers such as potato $\left(58-65^{\circ} \mathrm{C}\right)$ and cassava $\left(52-65^{\circ} \mathrm{C}\right)$ is slightly lower than for starches from cereals such as corn $\left(62-80^{\circ} \mathrm{C}\right)$ and wheat $\left(59-85^{\circ} \mathrm{C}\right)($ Singh et al., 2011). All values described for the other raw materials are below the ones found for peach palm flour, which is important to suggest possible industrial applications since heating with excess water causes irreversible swelling of starch granules and makes them too sensitive to mechanical and thermal stress. Since peach palm flours have high gelling temperature, they may be used in products that need long processing under high temperature and constant stirring such as sauces (Adebowale et al., 2005).

The peak viscosity at a given concentration is an important characteristic that distinguishes different starchy materials. Each flour had different peak viscosity as they have different compositions. The maximum viscosity value of MAF, $454.00 \pm 2.00 \mathrm{cp}$, is significantly higher than the others since this sample had higher carbohydrate content. The maximum viscosity results found herein are similar to that of Arracacia xanthorrhiza $(440 \mathrm{cp}$ ) and different from the values found for starches from potato, sweet potato, Arracacia xanthorrhiza Bancroft, cassava, regular corn, and waxy corn of $750,250,280,250,160$, and 220 cp, respectively, when analyzed in water (Takizawa et al., 2004).

The profile values for tendency to downgrading were much lower for MIF and MEF. This is due to the higher contents of of lipids in these flours, which, when interacting with the starch granules, do not allow the formation of hydrogen bonds, different from that of MAF. MAF has high viscosity breakdown, which reveals the fragility of the starch granules present in the composition of this flour (Singh et al., 2011).

The flours had high water absorption values, significantly different among themselves. MEF had the highest value, which is justified by the higher concentration of insoluble fibers in that sample compared to MIF and MAF (Table 4). The high water absorption capacity is a relevant property for the application of flours in meat products, breads, and cakes (Porte et al., 2011). Using peach palm flours in those food systems may be desirable since it is gluten free (Clement \& Urpí, 2005), which allows it to replace wheat and other raw materials that contain gluten in different products to meet the demand of consumers with difficulty to digest that protein or who personally chose gluten-free diets.
Table 4. Technological properties of peach palm flour

\begin{tabular}{lcccc}
\hline Samples & WAC (\%) & OAC (\%) & EA (\%) & EE (\%) \\
\hline MIF & $270.32 \pm 0.84^{\mathrm{b}}$ & $65.25 \pm 0.38^{\mathrm{c}}$ & $4.92 \pm 0.07^{\mathrm{a}}$ & $4.28 \pm 0.07^{\mathrm{a}}$ \\
MEF & $291.73 \pm 0.64^{\mathrm{a}}$ & $102.07 \pm 0.53^{\mathrm{a}}$ & $4.73 \pm 0.07^{\mathrm{b}}$ & $4.42 \pm 0.11^{\mathrm{a}}$ \\
MAF & $255.57 \pm 0.89^{\mathrm{c}}$ & $90.48 \pm 0.70^{\mathrm{b}}$ & $4.67 \pm 0.07^{\mathrm{b}}$ & $3.60 \pm 0.14^{\mathrm{b}}$ \\
\hline
\end{tabular}

Mean values of three replicates with their standard deviations. Different letters among the rows represent difference at $95 \%$ significance.

The OAC values found were intermediate compared to other matrices such as peanut flour (200\%) (Beuchat et al. 1975), which suggests the flours, particularly MIF, are not appropriate to be used as the main ingredient of viscous products such as pastas. However, flours with low OAC are indicated for breading since they reduce fat absorption by the processed food during frying (Bolanho et al., 2014). The EA and EE values of all flours were low compared to mixed rice and soybean flour (106\%) (Maia, 2000), which suggests the flours may not be used to replace ingredients in emulsion systems.

\section{Conclusion}

The peach palm flours showed important nutritional and energy values. The functional property analyses showed their potential use in the formulation of different cookies, cakes, and meat, bakery, and breaded products. Since peach palm flour is gluten free, it is an option of healthy raw material to prepare products targeted at specific consumers. It is considered a source of fibers and can be added to different products in order to meet the growing market demand. This new flour product is a viable alternative to replace wheat flour in the preparation of different products, besides adding nutritional value to them.

\section{Acknowledgements}

The authors thank PROPESP/UFPA (Provost's Office for Research and Graduate Studies of the Federal University of Pará), $\mathrm{CNPq}$ (National Research and Development Council, processes 308021/2015-0 and 477013/2013-282 9), and CAPES (Coordination for the Improvement of Higher Education Personnel).

\section{References}

Adebowale, K. O., Afolabi, T. A., \& Olu-Owolabi, B. I. (2005). Hydrothermal treatements of finger millet (Eleucine Corona) start. Food Hydrocolloids, 19(6), 974-983. http://dx.doi.org/10.1016/j. foodhyd.2004.12.007.

American Association of Cereal Chemists - AACC. (2000). Approved methods (2 vols., 8th ed.). Saint Paul: AOAC. 
Association of Official Analytical Chemists - AOAC. (2002). Official Methods of Analysis of Association of Official Analytical Chemists (17th ed.). Washington: AOAC.

Beuchat, L. R., Cherry, J. P., \& Quinn, M. R. (1975). Physicochemical properties of peanut flour as affected by proteolysis. Journal of Agricultural and Food Chemistry, 23(4), 616-620. http://dx.doi. org/10.1021/jf60200a045. PMid:237951.

Bolanho, B. C., Danesi, E. D. G., \& Beléia, A. P. (2014). Characterization of flours madefrom peach palm (Bactris gasipaes Kunth) by-products as a new food ingredient. Journal of Food and Nutrition Research, 53(1), 51-59.

Brasil, (1978, Julho 24). Resolução CNNPA No 12, de 24/07. Regulamento técnico sobre padrões de identidade e qualidade da farinha de trigo. Diário Oficial da União, Brasília.

Brasil, Ministério da Saúde. (2012). Resolução n 54. Dispõe sobre o Regulamento Técnico sobre Informação Nutricional Complementar. Diário Oficial da União, Brasília.

Buttriss, J. L., \& Stokes, C. S. (2008). Dietary fibre and health: an overview. Nutrition Bulletin, 33(1), 186-200. http://dx.doi.org/10.1111/j.14673010.2008.00705.x.

Chaudhary, V. K., \& Weber, F. E. (1990). Barley flour evaluated as dietary fibre ingredient in wheat bread. Cereal Foods World, 35, 560-562.

Clement, C. R., \& Urpí, J. M. (2005). Phenotypic variation of peach palm observed in the Amazon basin. In C. R. Clement \& L. Coradin (Eds.), Peach palm (Bactris gasipaes H.B.K.) germplasm bankU.S. Agency for International Development (Final Report Revised, Grantnumber DAN-5542-G-SS-2093-00, pp. 20-54). Manaus: Instituto Nacional de Pesquisas da Amazônia, Centro Nacional de Recursos Genéticos/Embrapa.

Cooper, K. (1995). Fourier transform infrared spectroscopy investigations of protein structure. In J. Herron, W. Jiskott \& D. Crommelin (Eds.), Physical methods to characterize pharmaceutical proteins (pp. 101142). New York: Plenum Press. http://dx.doi.org/10.1007/978-14899-1079-0_3.

Cremer, D. R., \& Kaletunç, G. (2003). Fourier transform infrared microspectroscopic study of the chemical microstructure of corn and oat flour-based extrudates. Carbohydrate Polymers, 52(1), 53-65. http://dx.doi.org/10.1016/S0144-8617(02)00266-7.

Dench, J. E., Rivas, R. N., \& Caygill, J. C. (1981). Selected functional properties of sesame (Sesamum indicum L.) flour and two protein isolates. Journal of the Science of Food and Agriculture, 32(6), 557564. http://dx.doi.org/10.1002/jsfa.2740320606.

Ferreira, C. D., \& Pena, R. S. (2003). Comportamento higroscópico da farinha de pupunha (Bactris gasipaes). Boletim da Sociedade Brasileira de Ciência e Tecnologia de Alimentos, 23(2), 251-255. http://dx.doi. org/10.1590/S0101-20612003000200025.'

Hiane, P. A., Bogo, D., Ramos, M. I. L., \& Ramos, M. M. Fo. (2003). Carotenóides pró-vitamínicos A e composição em ácidos graxos do fruto e da farinha do bacuri (Scheelea phalerata Mart.). Food Science and Technology (Campinas), 23(2), 206-209. http://dx.doi. org/10.1590/S0101-20612003000200018.

Linet, M. J. Y., Humbert, E. S., \& Sosulski, F. W. (1974). Certain functional properties of sunflower meal products. Food Science and Technology (Campinas), 39(2), 368-370.
Maia, L. H. (2000). Características químicas e propriedades funcionais do mingau desidratado de arroz e soja e, propriedades reológicas e sensoriais deste mingau reconstituído. Seropédica: Universidade Federal Rural do Rio de Janeiro.

Neves, L. C., Campos, A. J., Benedette, R. M., Tosin, J. M., \& Chagas, E. A. (2012). Caracterização da capacidade antioxidante de frutas Nativas da Amazônia brasileira. Brazilian Journal of Fruit Growing, 34(4), 1165-1173.

Porte, A., Silva, E. F., \& Almeida, V. D. S. (2011). Propriedades funcionais tecnológicas das farinhas de sementes de mamão (caricapapaya) e de abóbora (cucurbita sp). Brazilian Journal of Agroindustrial Products, 13(1), 91-96.

Ribeiro, E. P., \& Seravalli, A. G. (2004). Química de alimentos (1. ed). São Paulo: Blucher Ltda.

Santos, A. F., Corrêa, C. Jr., \& Neves, E. J. M. (2008). Palmeiras para produção de palmito: juçara, pupunheira e palmeira real. Colombo: Embrapa Florestas.

Santos, A. F., Neves, D. J. M., Kalil, A. N. Fo., \& Penteado, R. J. Jr. (2011). Uso da pupunheira na agricultura familiar. Pelotas: Cultivar.

Santos, M. F. G., Alves, R. E., Brito, E. S., Silva, S. M., Silveira, M. R. S. (2017). Quality characteristis of fruits and oils of palms native to the brazilian amazon. Brazilian Journal of Fruit Growing, 39, e305.

Sena, L. M., Zucolotto, S. M., Reginatto, F. H., Schenkel, E. P., \& Lima, T. C. M. (2009). Neuropharmacological Activity of the Pericarpo of Passifl ora edulis fl avicarpa Degener: Putative Involvement of C-glycosylfl avonoids. Experimental Biology and Medicine, 234(8), 967-975. http://dx.doi.org/10.3181/0902-RM-84. PMid:19491371.

Singh, S., Singh, N., \& MacRitchie, F. (2011). Relationship of polymeric proteins with pasting, gel dynamic- and dough empirical-rheology in different Indian wheat varieties. Food Hydrocolloids, 25(1), 19-24. http://dx.doi.org/10.1016/j.foodhyd.2010.05.001.

Smith, A. L. (1979). Applied infrared spectra. New York: John Wiley \& Sons.

Sosulski, F. N. (1962). The centrifuge method for determining flour absortion in hard red spring wheats. Cereal Chemistry, 39(4), 344-350.

Takizawa, F. F., Silva, G. O., Konkel, F. E., \& Demiate, I. M. (2004). Characterization of tropical starches modified with potassium permanganate and lactic acid. Journal Brazilian Archives of Biology and Technology, Curitiba, 47(6), 921-931. http://dx.doi.org/10.1590/ S1516-89132004000600012.

United State Department of Agriculture - USDA. (2002). Nutrient database for standard - Reference - Release 15: nutrient. Beltsvile: Beltsvile Research Center.

Watt, B, Merrill, AL. (1963). Composition of food: raw, processed, prepared. Washington: Consumer end Food Economics Research Division Agri Res.

Yuyama, L. K. O. (2011). Uso de frutos da pupunheira para alimentação humana. Brasília: CEPLAC. Retrieved from http://www.ceplac. gov.br/paginas/pupunheira/download/CDTrabalhos/palestras/ Lucia\%20K\%20O\%20Yuyama\%2020Uso\%20de\%20furtos\%20 da\%20pupunheira\%20para\%20alimenta\%C3\%A7\%C3\%A3o\%20 humana.pdf 